\title{
SOCIAL PLURALISM IN PUBLIC AND PRIVATE TELEVISION BROADCASTING
}

\begin{abstract}
This paper measures social pluralism in the most popular free-to-air TV groups in Italy (Rai, a state-controlled company, and Mediaset, owned by Berlusconi's family) between 2008 and 2014. Media social pluralism is the ability of the mass media to describe and take into account the different categories of citizens in a society. The Italian Authority for Telecommunications regularly collects data on the airtime devoted to 22 "social actors" during newscasts. Our findings show that the public TV broadcaster shows a wider internal social pluralism than Mediaset. The data also reveal significant inter-group differences (external pluralism). The degree of internal and external pluralism decreased when Silvio Berlusconi served as Prime Minister.
\end{abstract}

Keywords. Social pluralism, mass media, television, public broadcasting. 


\section{SOCIAL PLURALISM IN PUBLIC AND PRIVATE TELEVISION BROADCASTING}

\section{Introduction}

Freedom of speech and expression is fundamental to liberal democracies. However, freedom of expression can only be implemented in a pluralistic media environment. In the last fifty years pluralism has been frequently associated with the diversity of opinions and points of view that the mass media convey. The intersections between the mass media and the various forms of pluralism are so widespread that the European Union, in 2009, launched a project to assess the risks for media pluralism in the EU Member States (Media Pluralism Monitor) and to measure the degree of pluralism in some Members of the European Union with a set of indicators (http://cmpf.eui.eu/). The Federal Communication Commission also commissioned a number of studies between 2006 and 2010 to address the diversity of media content and its relationship with market structure and intensity of competition (https://www.fcc.gov/general/2010media-ownership-studies).

However, the social dimension of pluralism has been rarely explored. Social pluralism has a wide-ranging scope since it regards cultural, ethnic, professional, political, institutional and geographical differences. This paper concentrates on social pluralism in the media, which is the ability of the mass media to describe and take into account the different categories of citizens in a society. Hence, the present study adopts what Valke (2011) calls the "reflective dimension" of pluralism, which "can be conceived and interpreted in a socio-demographic sense to refer to the proportional representation of different communities in the media" (p. 207).

Our empirical analysis concerns the degree of social pluralism in the most popular free-to-air TV platforms in Italy (Rai and Mediaset) between 2008 and 2014. The data were collected by the Italian Authority for Telecommunications and Media Industries (AgCom) and consist of the airtime devoted, during newscasts, to distinct and representative social categories of Italian society ("social actors"). To our knowledge, this is the first systematic data collection and measurement of social pluralism by an authority in an advanced country.

We had three main objectives. Firstly, we aimed to assess the degree of internal social pluralism, that is, the distribution of airtime amongst social actors within the state-controlled TV channels ${ }^{1}$ (Rai 1, Rai 2 and Rai 3) and, separately, within the three Mediaset channels controlled by Berlusconi's family (Rete 4, Canale 5 and Italia 1). Internal pluralism is important for many reasons. For example, much legislation explicitly 
considers internal pluralism as one of the main objectives of public broadcasting (for example, the "Mammì Bill" in Italy, issued on 6 August 1990, the Polish Broadcasting Act in 1992, and the Spanish Act 17/2006 of 5 June 2006 on National Public Radio and TV). In addition, the private or public control of a TV "group" would be barely defensible without a minimum level of content diversity between the group's channels. Secondly, we evaluated the differences in social pluralism between private and state-controlled free-to-air television channels (external pluralism). Rai and Mediaset have dominated Italian television broadcasting since the adoption of the Mammì Bill in 1990, which sanctioned the status quo and left Berlusconi's control over commercial television unchallenged. External pluralism can balance the risk of homogenization in a quasi-duopoly television system, where competition for viewers can lead to minimal differentiation of television content. This analysis is also interesting in terms of observing which categories of social actors are favoured by each platform ${ }^{2}$.

Thirdly, we studied the degree of stability of social pluralism by assessing whether the distribution of airtime across social actors was affected by Berlusconi's cabinet (2008-2011). If public and private channels are slanted towards specific and different social classes, such differences should have decreased when Berlusconi controlled both Rai and Mediaset, though indirectly.

This paper does not deal with the "optimal" distribution of TV airtime among social actors, for two reasons. First, AgCom collects airtime data without considering the possible overlap of social actors. Hence, we cannot ascertain whether the airtime devoted to one social actor is proportional to his/her relative weight in society. Second, the share of people belonging to a social category does not necessarily reflect its political, social, economic or cultural importance in a given society, which is subjective: each social actor would argue that he/she merits more attention.

We can sum up the results of our empirical analysis as follows. In terms of intra-group differences, the public TV broadcaster (Rai) shows a larger social pluralism than in private broadcasting (Mediaset). The degree of internal social pluralism of public TV is asymmetric, because one of its channels (Rai 3 ) is significantly different from the others (Rai 1 and Rai 2). The data also reveal significant inter-group differences (external pluralism). Rai assigns more airtime to supranational actors, the European Union, actors related to the Italian constitution, non-Italian political and institutional actors, trade unions, professional associations and individuals related to arts and culture. On the other hand, Mediaset favours public institutions, military and police forces, mass media, professionals, criminal offenders and ordinary people. Most of the differences relate to "speaking time". Finally, the differentiation between Rai and Mediaset is fairly stable, although selected exogenous factors affect the degree of social pluralism of Rai and Mediaset in the period under review. In particular, Berlusconi's administration is negatively and significantly correlated with internal and external pluralism. 
The next section briefly reviews the literature related to social pluralism. The third section outlines the institutional and economic framework of the Italian broadcasting system. The fourth section describes the data and presents the summary statistics, while the fifth section reports the results of the empirical analysis. The last section concludes the paper by discussing the limitations of the present research and its possible future developments.

\section{Related literature}

The economic literature regarding diversity in media markets has rarely dealt with social issues, but at the same time provides an important theoretical background to the present analysis. Since Steiner's seminal study in 1952, much research has explored the incentive of TV stations, newspapers and other media outlets to provide content variety (Spence and Owen, 1977; Waterman, 1990; Rogers and Woodbury, 1996; Gabszewicz et al., 2001; Mangani, 2003; Gal-Or and Dukes, 2003; Gabszewicz et al., 2004; Waterman, 2005 among others).

Advertising-based companies are motivated to provide popular content (information or entertainment) to satisfy the preferences of large mass audiences, because the advertisers' willingness to pay increases with audience size. This strategy may lead to minimal content differentiation and harsh competition between media companies, and few firms will deliberately provide specialized and less popular content to satisfy the preferences of niche audiences. In this respect, free-to-air TV is an appropriate unit of analysis: advertising is the only source of income (apart from licence fee-based contributions in state-controlled TV services) and a large audience is required in order to break even. From the perspective of social representation, large groups of citizens, compared to minorities, have a greater ability to organize their interests and be visible in the mass media. Public broadcasting can alleviate this asymmetry and ensure all social actors have visibility on TV and the opportunity to express their ideas without too much mediation (granting, for example, minimum speaking time during newscasts). The focus on minorities is thus a major goal of public broadcasting, in addition to ensuring universal geographical accessibility, contributing to national identity and sense of community, and guaranteeing distance from vested interests (Cushion, 2012). As explained by Rennhoff and Wilbur (2014), media diversity is a multidimensional concept because it regards the source of content (for example, how many media companies are active in a specific industry), the characteristics of content (which topics are covered and the space devoted to each topic), and the way content is presented (viewpoint diversity). While several studies have analysed content diversity from an empirical perspective, the measurement of viewpoint diversity raises serious questions, since it depends both on the preferences of users (e.g., readers, viewers) and on the different media content ${ }^{3}$. The methodology of this paper is similar to that used by George and Oberholzer-Gee (2011), who consider the issues covered in news programmes in order to calculate an index of media diversity. However, our 
contribution differs from previous studies in two respects. Firstly, our concept of "social pluralism" lies between content diversity and viewpoint diversity, since we consider the distribution of the TV airtime across different social actors. Thus, diversity is provided by the programming choice of TV stations and by the participation of social actors who have the opportunity to express their viewpoint. Secondly, this paper compares public and private broadcasting in terms of social pluralism, given the importance of public TV stations in Europe. Hence, we do not consider the impact of media ownership changes on media diversity (also because the Italian television industry has been structurally paralysed over the last thirty years). A closely related paper to ours is Durante and Knight's (2012), who show that the news content of the Italian public broadcasting service is affected by the identity of the political majority. In addition, Durante and Knight (2012) used individual survey data and found evidence that viewers respond to changes in the political majority by modifying the choice of their favourite news programs. The political slant of newspapers and TV channels arises through explicit endorsement, the deliberate choice of words and expressions or coverage of topics appreciated by specific social classes. Political bias and social bias are thus strictly related. The decision to allocate more airtime to a specific social class denotes the intention to satisfy its political preferences, especially when the political orientation within that social class is sufficiently homogeneous.

Finally, this paper draws upon a number of studies in the social and political sciences that focus on the intersection between the normative/positive aspects of pluralism and the role played by the mass media (Humphreys, 1996; Gunther and Mughan, 2000; Besley et al., 2002; Hitchens, 2006; Czepek et al., 2009; Chomsky and Herman, 2010). These works explore the multiple dimensions of social and cultural pluralism in detail. However, they have rarely explored the quantitative dimension of the issues debated.

\section{The Italian television broadcasting system: main characteristics}

Two main national companies dominate the Italian (free) broadcasting television system. Rai, the statecontrolled company, and Mediaset, controlled by Berlusconi's family through the Fininvest holding. Both companies operate three major national terrestrial TV stations: Rai 1, Rai 2 and Rai 3 on the one hand, and Canale 5, Italia 1 and Rete 4 on the other. Rai and Mediaset together have a share of approximately $90 \%$ of the TV audience of free terrestrial digital television. The closest competitor, La7, formerly controlled by the Telecom group and purchased by Cairo Communications in 2013, had an audience share of $4-5 \%$ in January 2014

Mediaset was founded by Silvio Berlusconi and developed throughout the 1980s and the early 1990s. Berlusconi became the main candidate of the centre-right coalitions in 1994 and abandoned formal management of his media group. However, the control of Mediaset by Berlusconi's family, in particular through his daughter Marina and son Piersilvio, has always been clear and consistent. This situation, which 
is unique in advanced countries, has raised serious concerns regarding a conflict of interest. The concerns were amplified when Berlusconi was the Italian Prime Minister (1994; 2001-2005; 2005-2006; 2008-2011). In fact, the political majority is strictly linked to the Rai group and the Ministry of Economy and Finance formally owns the Rai company 4 . Many argue that during his cabinet, Berlusconi was able to virtually control the information and entertainment content of broadcasting television (Hine, 2001; Hibberd, 2007). At the beginning of the 21st century, the broadcasting dominion of Rai and Mediaset was threatened by several events. First, Sky TV, using the satellite platform, consistently increased its audience, convincing Italian viewers to pay to access some programs, especially sports and movies. Broadly speaking, the development of pay TV has led to a decline in the advertising revenues of free-to-air TV channels. Second, the digital television transition, which started in 2008 and was completed in 2012, expanded the number of frequencies available to operators and viewers, bringing more competition and market fragmentation. In theory, a higher number of channels increases content diversity, with some channels being explicitly devoted to specific topics. Thus, the digital system has benefited viewers/consumers as a consequence of an enhanced matching between heterogeneous preferences and program characteristics.

At the same time, Rai and Mediaset have continued to control the market with their old and new digital channels. Rai operates eleven channels in addition to the three major ones, while Mediaset has launched eight new channels. In November 2014, the six most popular channels in the old analogue system (Rai 1, Rai 2, Rai 3, Canale 5, Retequattro, Italia 1) maintained a large market share: according to Auditel ${ }^{5}$, together they held an average share of $62 \%$ between 20.30 and 22.30 . In terms of all the digital terrestrial channels, Mediaset and Rai had a share of $74.2 \%$ (both shares are calculated from total digital terrestrial platforms, that is, advertising-based and pay TV stations).

\section{Data and summary statistics}

The Italian independent authority for telecommunications and mass media industries (AgCom) is the main data source. AgCom is responsible for "ensuring equitable conditions for fair market competition and protecting the fundamental rights of all citizens". AgCom conducts a monthly review of the "social actors" that appear in the most popular free-to-air television channels: Rai 1, Rai 2, Rai 3, Canale 5, Retequattro, Italia 1, La 7, plus other free digital terrestrial channels with smaller audiences: La7d, MTV Italia, SkytgRai24, Cielo, La Effe, Deejay Tv.

The social actors are included in a list of 22 macro-categories: supranational actors (UN, NATO, etc.), European Union (European Commission, European Parliament, etc.), constitutional actors (Head of State, Prime Minister, etc.), public institutions (Antitrust Authority, AgCom, etc.), non-Italian political and institutional actors, political parties and movements, local institutions, magistrates and courts, military and police forces, the Vatican and other religious institutions, relevant associations for social pluralism 
(sustainability organizations, consumer associations, etc.), "special" actors (children, senior citizens, youth, disabled, etc.), economic and financial institutions (banks, insurance companies, etc.), trade unions and professional associations, mass media, professionals, research institutions, scientists and experts, individuals related to arts and culture (e.g., artists, cultural foundations) and show business, athletes active in sports competitions, individuals related to crime (e.g., suspects, prisoners, victims), and ordinary citizens. The empirical analysis considers only the major public TV channels (Rai 1, Rai 2, Rai 3) and the Mediaset channels (Retequattro, Canale 5, Italia 1 ) and focuses on the AgCom data collected during the newscasts. In fact, newscasts have two important characteristics: regularity and popularity, thus making the data stable and homogeneous enough to be analysed statistically. To measure the frequency of social actors during TV newscasts, AgCom calculates the news time, speaking time and broadcasting time. The news time is the airtime devoted to the coverage of questions and events associated with a social actor. The speaking time is the airtime in which a social actor speaks directly to the public through statements or interviews, and the broadcasting time is the sum of speaking time and news time.

The distinction between news and speaking time is important and affects the interpretation of the results. News time can include both positive and negative reports, while speaking time is an opportunity for a social actor to express his/her views without mediation, although journalists and interviewers can affect the emotional response of the audience before, during and after the appearance of a social actor. The dataset ranges from the beginning of the AgCom monitoring in January 2008 to August 2014 (with some months missing), with a total of 1584 observations for each channel. Table 1 aggregates the observations of the Rai and Mediaset channels and shows the share of airtime devoted to social actors. Looking at total airtime, constitutional actors and political parties are given the highest visibility. If we consider Rai and Mediaset together, constitutional and political actors account for $61 \%$ of total airtime. For example, the average time devoted on a monthly basis to political parties and movements is 65 hours, 51 minutes and 15 seconds. Other actors with high visibility are foreign politicians, the Vatican, trade/labour unions, and individuals linked to crime. 
TABLE 1

Percentage of airtime devoted to social actors in free-to-air Italian TV newscasts, January 2008 - August 2014

\begin{tabular}{|c|c|c|c|c|c|c|c|}
\hline & & \multicolumn{3}{|c|}{ Rai } & \multicolumn{3}{|c|}{ Mediaset } \\
\hline & Social actors & NT & $S T$ & $B T$ & NT & ST & $B T$ \\
\hline 1 & Supranational actors & $1.0 \%$ & $0.3 \%$ & $0.8 \%$ & $0.7 \%$ & $0.1 \%$ & $0.5 \%$ \\
\hline 2 & European Union & $2.4 \%$ & $0.6 \%$ & $1.8 \%$ & $1.8 \%$ & $0.6 \%$ & $1.3 \%$ \\
\hline 3 & Constitutional actors & $32.0 \%$ & $23.3 \%$ & $29.2 \%$ & $29.9 \%$ & $19.4 \%$ & $25.7 \%$ \\
\hline 4 & Public Institutions & $1.2 \%$ & $1.2 \%$ & $1.2 \%$ & $1.1 \%$ & $1.8 \%$ & $1.4 \%$ \\
\hline 5 & Non Italian political and institutional actors & $7.1 \%$ & $0.4 \%$ & $4.9 \%$ & $6.5 \%$ & $0.2 \%$ & $4.0 \%$ \\
\hline 6 & Political parties and movements & $34.4 \%$ & $31.2 \%$ & $33.4 \%$ & $31.9 \%$ & $33.9 \%$ & $32.7 \%$ \\
\hline 7 & Local institutions & $2.7 \%$ & $3.4 \%$ & $2.9 \%$ & $3.2 \%$ & $2.6 \%$ & $2.9 \%$ \\
\hline 8 & Magistrates and courts & $1.1 \%$ & $3.3 \%$ & $1.8 \%$ & $1.5 \%$ & $2.3 \%$ & $1.8 \%$ \\
\hline 9 & Military and police forces & $0.7 \%$ & $3.4 \%$ & $1.5 \%$ & $1.3 \%$ & $3.0 \%$ & $2.0 \%$ \\
\hline 10 & Vatican and other religious institutions & $4.8 \%$ & $3.5 \%$ & $4.4 \%$ & $4.8 \%$ & $2.0 \%$ & $3.7 \%$ \\
\hline 11 & Associations relevant for social pluralism & $0.5 \%$ & $1.7 \%$ & $0.9 \%$ & $0.5 \%$ & $1.0 \%$ & $0.7 \%$ \\
\hline 12 & Special actors & $0.1 \%$ & $0.8 \%$ & $0.4 \%$ & $0.2 \%$ & $0.6 \%$ & $0.3 \%$ \\
\hline 13 & Economic and financial institutions & $2.7 \%$ & $1.7 \%$ & $2.4 \%$ & $3.0 \%$ & $2.0 \%$ & $2.6 \%$ \\
\hline 14 & Trade unions and professional associations & $3.4 \%$ & $3.7 \%$ & $3.5 \%$ & $3.1 \%$ & $2.4 \%$ & $2.8 \%$ \\
\hline 15 & Mass media & $0.8 \%$ & $2.7 \%$ & $1.4 \%$ & $0.9 \%$ & $5.5 \%$ & $2.8 \%$ \\
\hline 16 & Professionals & $0.3 \%$ & $3.3 \%$ & $1.2 \%$ & $0.4 \%$ & $3.6 \%$ & $1.7 \%$ \\
\hline 17 & Research institutions, scientists and experts & $0.2 \%$ & $1.5 \%$ & $0.6 \%$ & $0.2 \%$ & $1.1 \%$ & $0.6 \%$ \\
\hline 18 & Individuals related to arts and culture & $0.1 \%$ & $0.4 \%$ & $0.2 \%$ & $0.1 \%$ & $0.2 \%$ & $0.1 \%$ \\
\hline 19 & Individuals related to show business & $0.1 \%$ & $0.7 \%$ & $0.3 \%$ & $0.2 \%$ & $0.7 \%$ & $0.4 \%$ \\
\hline 20 & Athletes & $0.3 \%$ & $0.4 \%$ & $0.4 \%$ & $0.6 \%$ & $0.4 \%$ & $0.5 \%$ \\
\hline 21 & Individuals linked to crime & $3.9 \%$ & $5.5 \%$ & $4.4 \%$ & $8.0 \%$ & $7.8 \%$ & $7.9 \%$ \\
\hline 22 & Ordinary people & $0.0 \%$ & $7.2 \%$ & $2.3 \%$ & $0.0 \%$ & $8.6 \%$ & $3.5 \%$ \\
\hline
\end{tabular}

Notes. $\mathrm{NT}=$ news time. $\mathrm{ST}=$ speaking time. $\mathrm{BT}=$ broadcasting time. Broadcasting time is the sum of news and speaking time. Percentages are calculated on the news or speaking time devoted to social actors by each group.

The variability in social pluralism over the years is one of the focuses of the research. Figures 1 and 2 show the coefficient of variation of the share of airtime in Rai and Mediaset channels, split into news and speaking time. 


\section{FIGURE 1}

News time, normalized standard deviation, 2008-2014. Normalized standard deviation of the distribution of news time among 22 social actors on the $\mathrm{Y}$-axis. Months on the $\mathrm{X}$-axis.

Source: AgCom.

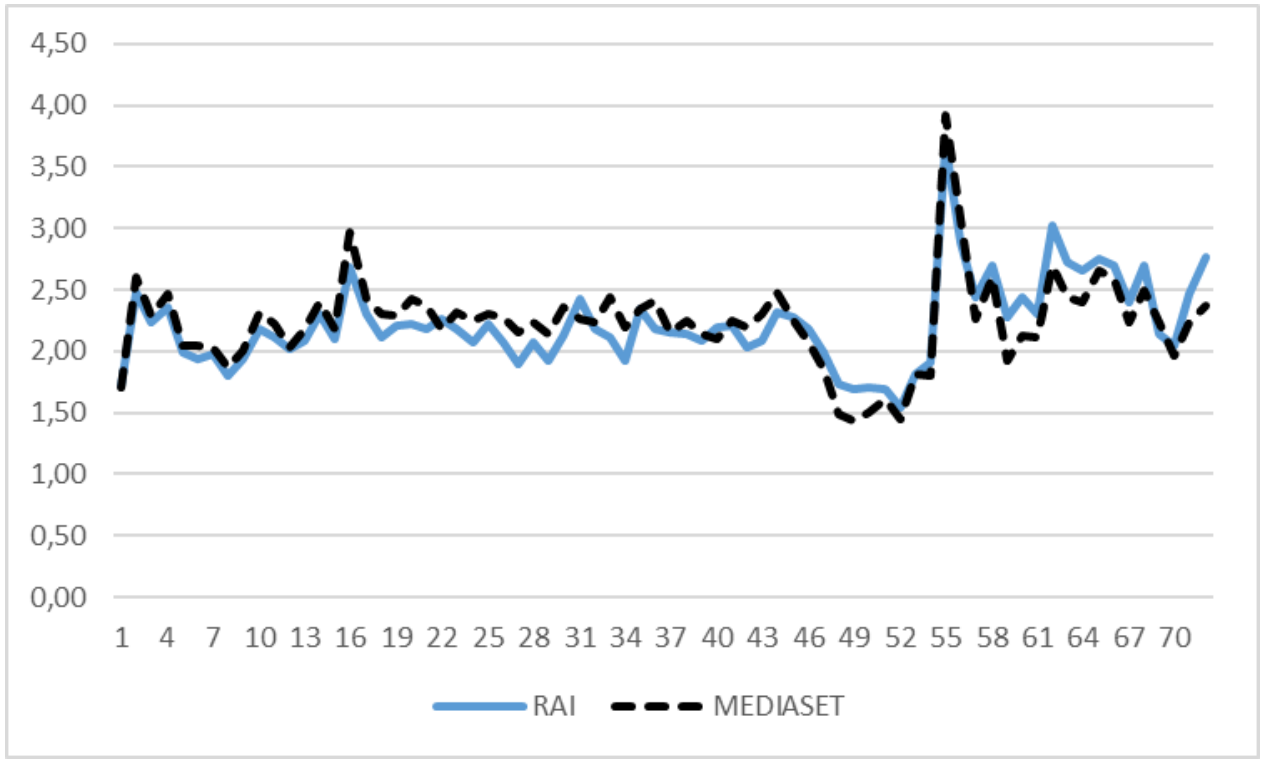

\section{FIGURE 2}

Speaking time, normalized standard deviation, 2008-2014. Normalized standard deviation of the distribution of broadcasting time among 22 social actors on the $Y$-axis. Months on the Xaxis.

Source: AgCom.

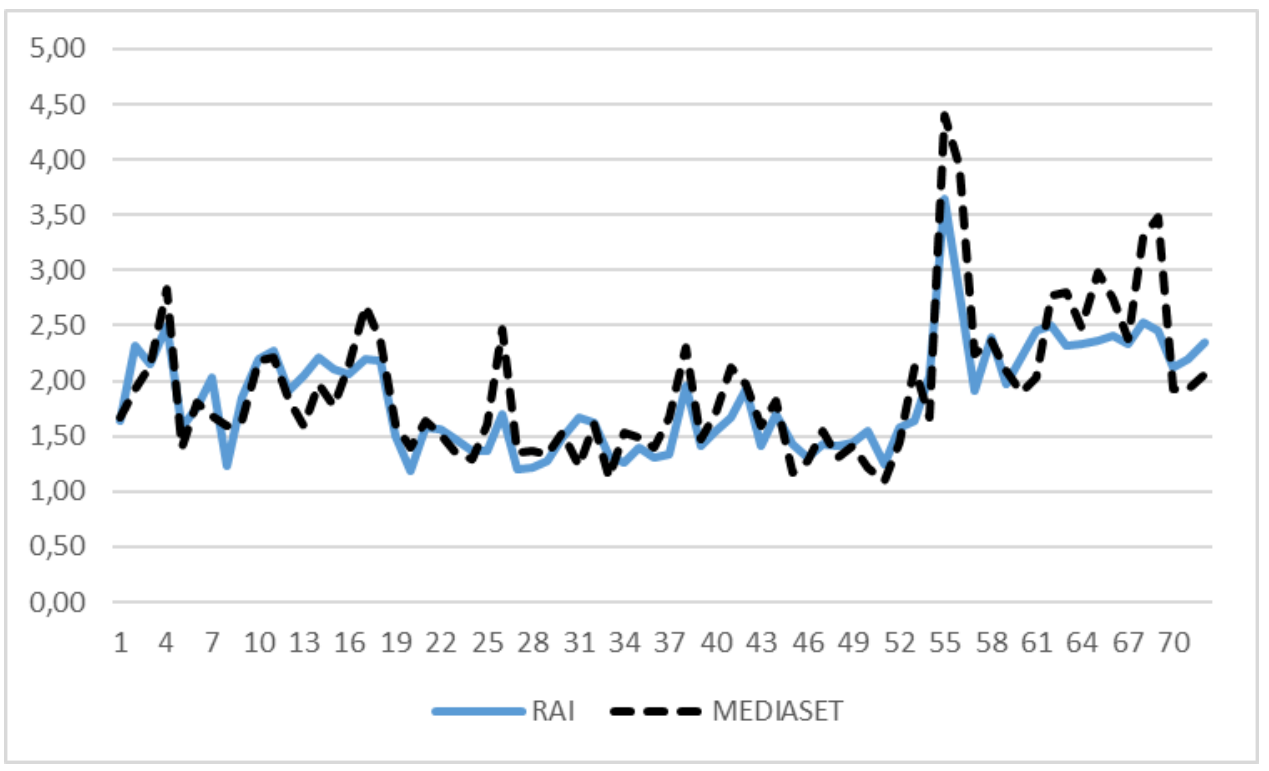

What is immediately evident is that the Rai and Mediaset series are similar both in terms of news and speaking time. In other words, the factors that affect the variance in airtime devoted to social actors, that 
is, the sequence and combination of events, have a similar impact on Rai and Mediaset newscasts. In addition, the coefficient of variation remains between 1.50 and 2.50. However, specific events (some of which will be considered in the next section) can alter the allocation of airtime across different social actors, they do not greatly affect the overall distribution of news and speaking time. The highest peak, for both series, occurred during the last electoral period: January-February 2013. Though similar, the Rai and Mediaset series shown in Figures 1 and 2 may hide some differences in the distribution of news and speaking time across different social actors. The next section sheds some lights on this issue.

\section{Empirical analysis}

Internal and external pluralism: basic measures

The first objective of the empirical analysis was to assess the degree of internal social pluralism. We investigated whether TV channels, within the public and private groups, differ in terms of airtime devoted, during newscasts, to social actors. The variable of interest is the share of airtime devoted to social actors 1 to 22 (see Table 1) in the 72 months under review. We thus measured the association between actors and channels within each group (that is, we considered $3 \times 22$ tables). Table 2 shows the results of a chi square test, along with Cramer's V, a relative index of association, for news time, speaking time and broadcasting time.

\section{TABLE 2}

Rai and Mediaset: internal and external social pluralism

\begin{tabular}{|c|c|c|c|c|}
\hline & & News time & Speaking time & Broadcasting time \\
\hline & $\mathrm{chi}^{2}$ & $1.0 \mathrm{e} 05^{* * *}$ & $1.3 \mathrm{e} 05^{* * *}$ & $2.1 \mathrm{e} 05^{* * *}$ \\
\hline \multicolumn{5}{|l|}{ RAI } \\
\hline & Cramer's V & 0.078 & 0.125 & 0.090 \\
\hline & $\mathrm{chi}^{2}$ & $1.9 \mathrm{e} 05^{* * *}$ & $5.3 e 05^{* * *}$ & $7.6 \mathrm{e} 05^{* * *}$ \\
\hline \multicolumn{5}{|l|}{ MEDIASET } \\
\hline & Cramer's V & 0.121 & 0.251 & 0.189 \\
\hline & chi $^{2}$ & $1.6 \mathrm{e} 05^{* * *}$ & $1.5 \mathrm{e} 05^{* * *}$ & $3.0 \mathrm{e} 05^{* * *}$ \\
\hline \multicolumn{5}{|l|}{ RAI/MEDIASET } \\
\hline & Cramer's V & 0.106 & 0.134 & 0.114 \\
\hline
\end{tabular}

The differences within the Rai and Mediaset channels are significant: Rai1, Rai2 and Rai3 differ in terms of airtime devoted to social actors, as do the Mediaset channels. At the same time, Mediaset shows a lower 
degree of internal pluralism compared to Rai: although the observed chi square for Mediaset channels is higher, the normalized measure of association (Cramer's $V$ ) reveals that the association between actors and channels is higher within the Mediaset group ${ }^{6}$. In both groups, the differences in speaking time prevail over the differences in news time. A proportion test (not shown here) reveals that the diversity within the Rai group is asymmetric: relative to broadcasting time, the difference between Rai 1 and Rai 2 is significant at the 0.01 level only for three social actors, while the Rai 3 newscasts show many significant differences compared to both Rai 1 and Rai 2. Within the Mediaset group, the differentiation between Retequattro, Canale 5 and Italia 1 channels is less asymmetric.

The combination of airtime that public or private channels devote to different actors determines the degree of external social pluralism. Here, we leave aside the individual channels and focus on the differences between the two groups in terms of the amount of coverage given to specific actors coverage. The last two rows of Table 2 show the results of a chi square test and a Cramer's $V$ test when we consider the Rai and Mediaset channels in aggregate. Again, the variable of interest is the share of airtime devoted to social actors 1 to 22 . The differences in the distribution of airtime across social actors between Rai and Mediaset are significant. A more detailed analysis (not presented here) reveals that, excluding differences with a $90 \%$ significance level, the Rai newscasts devote a higher share of airtime to supranational subjects, the European Union, constitutional subjects, non-Italian political and institutional subjects, associations relevant for social pluralism, trade unions, professional associations and persons related to arts and culture. On the other hand, Mediaset gives more coverage to public institutions, military and police forces, mass media, professionals, criminals and ordinary people. The newscasts do not differ in terms of the coverage of other social actors.

\section{The impact of exogenous factors on social pluralism}

The evaluation of social pluralism over several years is important as is the assessment of its stability (Iosifidis, 2010; Sukosd et al., 2015). Table 2 shows substantial intra-group and inter-group social pluralism. At the same time, the distribution of airtime across social actors within each group changes over time and that the variability is similar in each group (Figures 1 and 2). The same exogenous factors seem to change the incentive to cover different social actors through the news or speaking time. In what follows, we assess the impact of changes in the political majority (thus changes in government) on the measure of social pluralism in the Rai and Mediaset newscasts. Section 2 outlined the extraordinary scenario of the Italian mass media being inextricably linked with political affairs. While Silvio Berlusconi was the leader of the centre-right political coalition for a long time, his family still controlled a media corporation that included Mediaset and its television channels. If Rai and Mediaset, as shown in Table 1, devote airtime attention to different social actors, this difference may have shrunk when Berlusconi and his coalition controlled the 
public TV channels. Thus, the objective of the rest of the paper is to assess the impact of Berlusconi's III cabinet on social pluralism (May 2008-November 2011).

In addition, we control for other exogenous factors: the digital transition (2008-2012) and the economic recession (2009 to date). The digital transition began in 2008 and was fully operative in 2012. During this period, Rai, Mediaset and other groups launched new digital TV channels, many of which specialized in specific content (for example cartoons, news and sport). At the same time, Mediaset and Sky developed digital terrestrial or satellite pay-tv channels to satisfy viewers with heterogeneous preferences. Hence, the higher availability of specialized channels may have changed both Rai and Mediaset's interest in covering different social actors during the newscasts.

Similarly, the financial and economic crisis, which officially started at the end of 2008 and was still ongoing in Italy in 2014, could have involved more focus on specific categories of social actors, such as economic institutions or trade unions. This would then have affected the dispersion of broadcasting time across social actors, as well as concentrating the interest of both groups on similar actors, therefore reducing the intergroup differences.

Table 3 shows the results of an Ordinary Least Square analysis with, as the dependent variable, the normalized standard deviation of the coverage of social actors within the Rai and Mediaset newscasts (internal pluralism). The index is similar to that proposed by George and Oberholzer-Gee (2011), who calculated the standard deviation in category word shares across local TV stations, in order to measure issue diversity. The explanatory and control variables are a dummy variable equal to 1 if Berlusconi was the prime minister, 0 otherwise (Berlusconi), inhabitants receiving digital signals (digital), the number of subscriptions to Sky pay TV (pay), and the GDP growth considered on a monthly basis (GDP).

\section{TABLE 3}

Dispersion of the airtime between 2008 and 2014 (internal pluralism)

\begin{tabular}{lllllll}
\hline & \multicolumn{2}{l}{ News time } & \multicolumn{2}{l}{ Speaking time } & \multicolumn{2}{l}{ Broadcasting time } \\
\hline & Rai & Mediaset & Rai & Mediaset & Rai & Mediaset \\
\hline Berlusconi & $-0.012^{*}$ & $-0.102^{* *}$ & $-0.176^{* * *}$ & $-0.106^{* *}$ & $-0.057^{* *}$ & $-0.101^{* *}$ \\
& & & & & & \\
& $(0.007)$ & $(0.026)$ & $(0.035)$ & $(0.022)$ & $(0.010)$ & $(0.021)$ \\
digital & -0.015 & -0.014 & $-0.093^{*}$ & $-0.059^{*}$ & $-0.044^{*}$ & -0.042 \\
& $(0.017)$ & $(0.021)$ & $(0.044)$ & $((0.034)$ & $(0.028)$ & $(0.026)$ \\
pay & -0.253 & -0.428 & $-1.343^{*}$ & -1.786 & -0.704 & -1.338
\end{tabular}




\begin{tabular}{|c|c|c|c|c|c|c|}
\hline & (0.555) & $(0.668)$ & $(0.781)$ & (1.089) & (0.598) & $(0.848)$ \\
\hline \multirow[t]{2}{*}{$G D P$} & $-2.190 * * *$ & $-2.063^{* *}$ & $-5.271 * * *$ & $-5.487 * * *$ & $-3.435 * * *$ & $-4.081 * * *$ \\
\hline & $(0.725)$ & $(0.892)$ & $(1.160)$ & (1.618) & $(0.888)$ & $(1.260)$ \\
\hline \multirow[t]{2}{*}{ constant } & $28.885^{* *}$ & $28.832 * *$ & $75.171^{* * *}$ & $81.108 * * *$ & $47.635^{* * *}$ & $60.541 * * *$ \\
\hline & (11.739) & $(14.115)$ & (16.507) & $(23.022)$ & $(12.631)$ & (17.917) \\
\hline $\mathrm{R}^{2}$ & 0.393 & 0.406 & 0.569 & 0.378 & 0.484 & 0.382 \\
\hline DW statistics & 1.973 & 1.782 & 2.345 & 2.123 & 2.013 & 2.349 \\
\hline$n$ & 72 & 72 & 72 & 72 & 72 & 72 \\
\hline
\end{tabular}

Notes. OLS, standard errors in parentheses. The variable Berlusconi is a dummy. Other variables are in natural logs. Significance level: ${ }^{*} \mathrm{p}<0.10,{ }^{* *} \mathrm{p}<0.05, \mathrm{p} * * * 0.01$.

The dispersion of airtime across social actors is lower when Berlusconi was the prime minister. The magnitude and significance of the effect are similar in the two groups. The digital transition has a similar effect, although it is not always significant: the higher availability of content reduces the dispersion of airtime across social actors. The GDP exerts a (negative) significant effect on the dispersion of airtime across social actors: a higher GDP growth is combined with a higher homogeneity of the airtime devoted to social actors.

A similar analysis is applied to inter-group differences (external pluralism). Table 4 presents the dissimilarity between the Rai and Mediaset distribution of broadcasting time. The index of dissimilarity is the following:

$$
D_{X Y t}=0.5 \sum_{1}^{22}\left|\left(\frac{x_{i t}}{X_{t}}\right)-\left(\frac{y_{i t}}{Y_{t}}\right)\right|
$$

Where, at time $t, x_{i}$ and $y_{i}$ are the airtime devoted to social actor $i$ by Rai and Mediaset respectively, and $X$ and $Y$ are the total newscast airtime. 


\section{TABLE 4}

Dissimilarity between Rai and Mediaset, 2008-2014 (external pluralism)

\begin{tabular}{|c|c|c|c|}
\hline & News time & Speaking time & Broadcasting time \\
\hline \multirow[t]{2}{*}{ Berlusconi } & $-0.037^{* *}$ & $-0.016 *$ & $-0.159 * *$ \\
\hline & $(0.012)$ & $(0.010)$ & $(0.049)$ \\
\hline \multirow[t]{2}{*}{ digital } & 0.055 & 0.017 & 0.023 \\
\hline & $(0.059)$ & $(0.030)$ & $(0.040)$ \\
\hline \multirow[t]{2}{*}{ pay } & -2.456 & -0.594 & -0.647 \\
\hline & $(1.921)$ & $(0.974)$ & (1.293) \\
\hline \multirow[t]{2}{*}{ GDP } & -5.214 & 1.027 & -0.685 \\
\hline & $(2.854)$ & $(1.446)$ & $(1.920)$ \\
\hline \multirow[t]{2}{*}{ constant } & 84.827 & -3.655 & 0.529 \\
\hline & $(40.595)$ & $(20.574)$ & $(27.311)$ \\
\hline $\mathrm{R}^{2}$ & 0.269 & 0.122 & 0.396 \\
\hline DW statistics & 1.678 & 1.992 & 2.014 \\
\hline $\mathrm{n}$ & 72 & 72 & 72 \\
\hline Notes. OLS, sta & ard arrorci & arentheses. Si६̨ & ficance level: \\
\hline
\end{tabular}

Table 4 highlights two main results. First, the impact of the exogenous factors is not high. This result confirms the previous findings: the sequence of events affected the Rai and Mediaset distribution of airtime in a similar way. If Rai and Mediaset differ significantly in terms of attention devoted to social actors, this differentiation has been relatively stable, and public and private groups have adopted a sort of "social counterprogramming" over the years. Second, when Berlusconi was in power, the differentiation was less strong in terms of news time, speaking time and broadcasting time. This effect does not increase the significance of the whole model. However, the combination of private and public "control" of free-toair television is clearly associated with a lower degree of external social pluralism. 


\section{Discussion and Conclusions}

This paper has analysed the characteristics of social pluralism in the most popular Italian free-to-air TV groups: Rai, a state-controlled company, and Mediaset, controlled by Silvio Berlusconi's family. In this study, social pluralism is defined by the distribution of airtime (news time and speaking time) across 22 classes of social actors. The research had three objectives: first, to assess the intensity of internal pluralism, that is, the distribution of airtime across different actors within the same group. Second, to measure the differences between the two groups, again in terms of time devoted to "cover" social categories with news or speaking time. Third, to study whether exogenous factors, such as changes in the political majority, have affected the distribution of airtime across social actors. We conducted this research using data collected by AgCom between 2008 and 2014. Although the classification of social actors and the AgCom methodology could be refined, the data provide the opportunity to observe social media pluralism in action and measure it.

The results can be summarized as follows. The Rai group exhibits a greater internal social pluralism than Mediaset. Within the Rai group, Rai 1 and Rai 2 (the most popular public channels) present a sort of coordination in the distribution of airtime over social actors, while Rai 3 shows differs substantially from the other two Rai channels. Regarding external pluralism, the difference between Rai and Mediaset is significant and stable over time: some social actors systematically obtain more news and speaking time in the Rai newscasts, while others obtain more time in the Mediaset group ${ }^{7}$. Some institutional factors have had an impact on social pluralism. First, a favourable economic trend and the position of Silvio Berlusconi as prime minister negatively affected the dispersion of airtime across social actors (internal pluralism). Second, when Berlusconi was in power, the difference between the private and public television groups (external pluralism) was less pronounced.

The last finding is interesting in the light of the theory of content differentiation in media industries. In fact, a well debated theoretical result, originally proposed by Steiner (1952), is that advertising financed media focuses on popular content in order to maximize the "audience" and the advertisers' willingness to pay. A corollary is that without serious competitors in the market, a media monopolist will broadcast heterogeneous content to meet both the mass and niche preferences of consumers. Although several studies have amended Steiner's result and found important exceptions, the intuition of the original model still explains the frequent tendency of media companies to offer similar content.

This paper focuses on a special kind of content differentiation: the airtime devoted to different social actors in free-to-air television. The variable of interest in the paper is the distribution of time/space over different actors/issues. This point raises two important caveats. First, the content is already "internally differentiated" within each newscast, since the attention is distributed amongst multiple and different social actors. Second, the TV channels cannot interrupt the newscasts to broadcast advertising. Hence, the 
link between the choice of content, the maximization of audience and the advertisers' willingness to pay is less strong compared to the case of entertainment or sport content. The data cannot thus generate a minimal differentiation result in a Steiner-like way. Rather, the public broadcasting service seems to ensure a sort of "social counter-programming", at least when the same company/family does not directly or indirectly control both the public and the private TV groups.

These issues are part of a broader debate regarding the role and desirability of state-controlled TV companies. Several politicians, experts and economists argue that the justification for public TV is less clear than in the past (Brown, 1996; Collins et al., 2001; Armstrong, 2005; Hargreaves Heap, 2005; Bardoel and d'Haenens, 2008). Efficiency concerns, the risk of a conflict of interest between TV groups and political power, and the uncertain quality of services suggest the need for a reduction in public intervention in broadcasting and more space for private companies. For example, the representation of social classes in media outlets might be achieved by a regulation imposed on private companies if public broadcasting was abandoned. Unfortunately, the theoretical and empirical work on the theme has not clarified all the consequences of abandoning public TV, especially if some media moguls have a political agenda. In many countries, broadcast television is still the most important means for distinct social actors to be visible and express their ideas. However, "marginal" social actors struggle to be represented and to express their views, because their direct or indirect TV appearance does not maximize the broadcasters' advertising revenues. State-controlled TV stations can alleviate these problems, because the profit constraints are less binding, and can guarantee an adequate media coverage for majority and minority social actors. The analysis presented in this paper has some limitations. First, we only considered the airtime devoted to social actors during newscasts. This was dictated by the larger newscast audiences compared to other programs, as well as by the regularity of newscast audiences in TV channels: regularity and reliability of time schedules stabilize the unit of analysis and make the data across TV groups more homogeneous and easily comparable. However, public and private TV channels have other formats, such as talk shows or journalistic special reports, where politicians, experts and ordinary people state their views and challenge each other's opinions. Some of these programs focus heavily on social actors and present and discuss their perspectives in detail. Talk shows and special reports are strongly dependent on the events that put various actors in the public eye. This might thus increase the skewness of the airtime distribution in the short run, because such events also alter the distribution of broadcasting time in the newscasts. Thus, future research should consider the total broadcasting time of TV channels to better assess the space devoted to each social actor.

Another limitation regards the actual impact of social pluralism on TV viewers. In fact, we did not consider the absolute or relative audience of private and public newscasts. A TV company can try to adequately represent all actors in a society, which can also be observed in the data. At the same time, if such a TV 
broadcaster reaches a small proportion of total TV viewers, the "reflective" social pluralism achieved is not really effective. While we reduced this bias by focusing on the two most popular broadcasting companies, we believe that future research should deal with the efficacy of social pluralism and its actual perception by citizens. In addition, we did not take into account the possibility that many people watch the newscasts of both public and private TV channels ${ }^{8}$. Should this occur frequently, the concerns regarding the lack of social pluralism would be alleviated, because our data reveal an objective differentiation between private and public TV in terms of distribution of airtime across social actors.

Finally, we assumed that the more airtime devoted to a social actor, the higher the interest in "favouring" that actor and his/her views. However, some argue that while speaking time is a real opportunity for an actor to express his/her views without mediation, news time can include both positive and negative reports (Durante and Knight, 2012) ${ }^{9}$. Therefore, if two competing channels devote the same news time to a social actor, it is not clear whether they adopt the same attitude towards that actor. In reality, the speaking time is also not necessarily "positive" for the actor involved. For example, a TV journalist can emphasize the weaknesses of a particular opinion during an interview. Future work should thus investigate whether this empirical bias can be partially corrected.

\section{ACKNOWLEDGEMENTS}

We would like to thank Hugh Martin, Lapo Filistrucchi, Wilfred Dolfsma, Azzurra Valentini and an anonymous referee for their helpful comments.

\section{DISCLOSURE STATEMENT}

No potential conflict of interest was reported by the author.

\section{NOTES}

1. More precisely, the Italian public broadcasting service is controlled by the central government.

2. For example, some argue that individuals with more liberal views pay more attention to themes such as world affairs, labour and social issues, while conservative viewers are more interested in issues such as law and order, immigration and security (Durante and Knight, 2012). This issue fits the Italian economic and institutional situation particularly well, because the most popular private TV channels are controlled by the family of Silvio Berlusconi, who had been the leader of the right wing coalition since 1993, and thus are expected to reflect the views of more conservative citizens.

3. To overcome this difficulty, Rennhoff and Wilbur (2014) propose a market-based measure of viewpoint diversity. In relation to local television news, Rennhoff and Wilbur (2014) found that viewpoint diversity is 
apparently not associated with local media market ownership. Rennhoff and Wilbur (2012) and George and Oberholzer-Gee (2011) obtained similar results: market structure exerts little influence on diversity.

4. The Italian Parliament elects seven members of the Rai Administrative Council. The other two members are nominated by the Ministry of Economy and Finance. The Council appoints the Director-General. The DirectorGeneral and the members of the Administrative Council are appointed for a renewable three-year term.

5. Auditel is a company that collects audience data. Its shareholders comprise all Italian public and private television companies as well as advertiser and advertising agency associations.

6. The significance of Cramer's $V$ is the same as is calculated with Pearson's chi-squared test.

7. The association between favouring certain social actors and a right/left political orientation raises several issues, which we leave for future work.

8. See Brosius et al. (1992) and Meyer and Muthaly (2008) for related research. Unfortunately, no study reports concrete results regarding the loyalty of viewers to TV channels.

9. Although the majority of journalists view themselves as "neutral", they can still involuntarily affect the perceptions of the public (McCarthy and Dolfsma, 2014).

\section{REFERENCES}

Armstrong, Mark. 2005. “Public Service Broadcasting”. Fiscal Studies 26 (3): 281-299. doi:10.1111/j.14755890.2005.00013.x.

Bardoel, Jojannes, and Leen d'Haenens. 2008. "Reinventing Public Service Broadcasting in Europe:

Prospects, Promises and Problems." Media, culture, and society 30 (3): 337-355. doi: 10.1177/0163443708088791.

Besley, Timothy, Burgess, Robert, and Andrea Prat. 2002. Mass Media and Political Accountability. New York: World Bank.

Brosius, H. B., Wober, M., and Weimann, G. 1992. "The Loyalty of Television Viewing: How Consistent Is TV Viewing Behavior?" Journal of Broadcasting and Electronic Media 36 (3): 321-335. doi: 10.1080/08838159209364180.

Brown, A. 1996. "Economics, Public Service Broadcasting, and Social Values." Journal of Media Economics 9 (1): 3-15. doi: 10.1207/s15327736me0901_2.

Chomsky, Noam, and Edward S. Herman. 2010. Manufacturing Consent: The Political Economy of the Mass Media. New York: Random House.

Collins, Richard, Finn, Adam, McFadyen, Stuart, and Colin Hoskins. 2001. "Public Service Broadcasting Beyond 2000: Is There a Future for Public Service Broadcasting? Canadian Journal of Communication 26 (1). doi: 10.22230/cjc.2001v26n1a1192. 
Czepek, Andrea, Hellwig, Melanie, and Eva Nowak. 2009. Press Freedom and Pluralism in Europe: Concepts and Conditions. London: Intellect Books.

Cushion, S. 2012. The Democratic Value of News: Why Public Service Media Matter. London: Palgrave Macmillan.

Durante, Ruben, and Brian Knight. 2012. "Partisan Control, Media bias, and Viewer Responses: Evidence from Berlusconi's Italy." Journal of the European Economic Association 10 (3): 451-481. doi: 10.1111/j.1542-4774.2011.01060.x.

Gabszewicz, Jean, Laussel, Didier, and Nathalie Sonnac. 2001. "Press Advertising and the Ascent of the Pensée Unique." European Economic Review 45 (4): 641-645. doi: 10.1016/S0014-2921(01)00139-8.

Gabszewicz, Jean, Laussel, Didier, and Nathalie Sonnac. 2004. "Programming and Advertising Competition in the Broadcasting Industry." Journal of Economics and Management Strategy 13 (4): 657-669. doi 10.1111/j.1430-9134.2004.00027.x.

Gal-Or, Esther, and Anthony Dukes. 2003. "Minimum Differentiation in Commercial Media Markets." Journal of Economics and Management Strategy 12 (3): 291-325. doi: 10.1111/j.14309134.2003.00291.x.

George, Lisa M., and Felix Oberholzer Gee. 2011. "Diversity in Local Television News." US Federal Communications Commission Quadrennial Review, Washington, DC, July. Accessed at: http://www. fcc. gov/encyclopedia/2010-media-ownership-studies (December 3, 2017).

Gunther, Richard, and Anthony Mughan. 2000. Democracy and the Media: A Comparative Perspective. New York: Cambridge University Press.

Hargreaves Heap, Shaun P. 2005. "Television in a Digital Age: What Role for Public Service Broadcasting?" Economic Policy 20 (41): 112-157. doi: 10.1111/j.1468-0327.2005.00134.x.

Hibberd, Matthew. 2007. "Conflicts of Interest and Media Pluralism in Italian Broadcasting." West European Politics 30 (4): 881-902. doi: 10.1080/01402380701500363.

Hine, David. 2001. "Silvio Berlusconi, the Media and the Conflict of Interest Issue." Italian Politics 17 (1): 261-275. doi: 10.3167/ip.2001.170114.

Hitchens, Lesley. 2006. Broadcasting Pluralism and Diversity: A Comparative Study of Policy and Regulation. Oxford: Bloomsbury Publishing.

Humphreys, Peter. 1996. "Mass Media and Media Policy in Western Europe." Vol. 2. Manchester: Manchester University Press.

Iosifidis, Petros. 2010. "Pluralism and Concentration of Media Ownership: Measurement Issues." Javnostthe public 17 (3): 5-21. doi: 10.1080/13183222.2010.11009033.

Mangani, Andrea. 2003. "Profit and Audience Maximization in Broadcasting Markets." Information Economics and Policy 15 (3): 305-315. doi: 10.1016/S0167-6245(02)00112-9. 
McCarthy, Killian J., and Wilfred Dolfsma. 2014. "Neutral Media? Evidence of Media Bias and its Economic Impact." Review of Social Economy 72 (1): 42-54. Doi: 10.1080/00346764.2013.8061.

Meyer, Denny, and Siva Muthaly. 2008. “New Measures and a New Model for Television Network Loyalty (MOTNL)." Marketing Bulletin 19: 1-19. Accessed at: http://www.academia.edu/download/42279698/MB_V19_A1_214_Meyer.pdf (December 15 2017).

Rennhoff, Adam D., and Kenneth C. Wilbur. 2012. "Local Media Ownership and Media Quality." Information Economics and Policy 24 (3): 231-242. doi: 10.1016/j.infoecopol.2012.08.001.

Rennhoff, Adam D., and Kenneth C. Wilbur. 2014. "Market-based Measures of Viewpoint Diversity." Information Economics and Policy 26: 1-11. doi: 10.1016/j.infoecopol.2013.10.002.

Rogers, Robert P., and John R. Woodbury. 1996. "Market Structure, Program Diversity, and Radio Audience Size." Contemporary Economic Policy 14 (1): 81-91. doi: 10.1111/j.1465-7287.1996.tb00605.x.

Spence, Michael A., and Bruce Owen. 1977. "Television Programming, Monopolistic Competition and Welfare." Quarterly Journal of Economics 91 (1): 103-126. Retrieved from http://www.jstor.org/stable/1883140.

Steiner, Peter. 1952. "Program Patterns and Preferences, and the Workability of Competition in Radio Broadcasting." Quarterly Journal of Economics 66 (2): 194-223. doi: 10.2307/1882942.

Sukosd, Miklos, Picard, Robert, and Peggy Valcke, eds. 2015. Media Pluralism and Diversity: Concepts, Risks and Global Trends. London: Palgrave Macmillan.

Valcke, Peggy. 2011. "A European Risk Barometer for Media Pluralism: Why Assess Damage When You Can Map Risk?" Journal of Information Policy 1: 185-216. doi: 10.5325/jinfopoli.1.2011.0185.

Waterman, David. 1990. "Diversity and Quality of Information Products in a Monopolistically Competitive Industry." Information Economics and Policy 4 (4): 291-303. doi: 10.1016/0167-6245(89)90010-3.

Waterman, David. 2005. "Economics of Media Programming". In Handbook of Media Management and Economics, edited by Albarran, Alan B.., Chan-Olmsted, Sylvia M. and Michael O. Wirth. Mahwah NJ: Lawrence Erlbaum Associates. 